Salaries

\section{Physicists get on}

EITHER go west, or work for the government - that seems to be the inference that young British physicists will make from the latest remuneration survey among members of the Institute of Physics published in the most recent issue of Physics Bulletin (May 1980).

The figures now published show that the salaries of physicists working in the Civil Service consistently exceed those of academics and industrial physicists once the age of 40 has been passed. In the age group 55-59, the peak of physicists' earnings, the median salaries of those in the institute's two most highly qualified categories of membership (fellows and members) are now $£ 15,750$ p.a. for civil servants, £13,060 for academics and $£ 11,940$ for industrial physicists. The survey has shown the same pattern of salary differentials for the institute's membership as a whole.

The results of the latest survey show that there has been no radical change in the pattern of physicists' salaries since earlier surveys in 1977 and 1974. Broadly speaking, young people do best by working in industry immediately after graduation. Fellows and members of the institute in the age group 25-29 had median salaries (in 1980 ) of $£ 6,570$ p.a., compared with $£ 5,850$ and $£ 5,780$ in government service and the universities respectively. For these categories of membership, the financial advantages of industrial life persist until 35 , but in later age groups government physicists are ahead of those elsewhere.

Alternatively, the most highly qualified members of the institute can expect their salaries to increase during a working lifetime (between the age groups 25-30 and 55-59) from a median of $£ 5,850$ to a median of 15,750 , a ratio of 2.9 . The corresponding ratios for academics and those working in industry are respectively 2.26 and 1.82 .

The latest survey thus bears out the suspicion of many of those leaving universities, in other fields of science as well as physics, that industrial employment, although initially somewhat more rewarding in financial terms, offers a less dynamic pattern of employment than government service and academic life.

The latest survey also shows, however, that physicists have managed to keep up with inflation reasonably well in the past few years. In all categories of membership, and in all age groups, salaries have more than doubled since 1974.

The largest increases have however gone to the younger age groups and to those in the least qualified categories of membership (associate members and associates). Indeed, the median salary of associates of the institute in the age group 25-30 ( $£ 6,720)$ now exceeds that of the members of the same age ( $£ 6,290$ p.a.)

Proliferation

\section{Trimming sails}

Washington

More carrot, less stick. That is the message being given to President Carter by State Department officials as the US Administration reassesses its strategy for limiting the spread of nuclear weapons through unilateral controls on nuclear technology.

Staunch non-proliferationists in Congress and other parts of the Administration are demanding that the President stand firm, and in particular that he reject India's pending request for 39 tons of enriched uranium for its Tarapur power plant because of its refusal to accept international safeguards.

But elsewhere there is growing feeling that, in order to maintain credibility and effectiveness, the US must shift from the 'control and denial' aspects of nonproliferation strategy to emphasising the incentives for compliance offered by US promises of a 'reliable' supply of nuclear fuel and technology.

Such sentiments have risen to the surface following the completion in February of the International Nuclear Fuel Cycle Evaluation. Proposed by President Carter in 1977, INFC.E endorsed several aspects of US policy - but fell far short of endorsing all of them.

Supporters of the nuclear industry are now using the INFCE findings to challenge key aspects of Carter's policies. For example the House of Representatives Commerce Committee last week recommended that the Nuclear Regulatory Commission proceed with licensing review procedures for a new reprocessing plant; these were suspended in 1977 at the President's request, with the promise that the order would be re-examined after the completion of INFCE.

Despite indications of a possible relaxation, the Administration has given no sign that it intends to change its basic policy in the light of INFCE. Rather it is seeking ways to enhance its image as a reliable supplier of nuclear technology, within the provisions of the Nuclear NonProliferation Act of 1978.

The problem is that the act poses what Dr George Rathjens, professor of political science at the Massachusetts Institute of Technology and deputy to Mr Smith, calls a 'fundamental dilemma'.

"Our policy and our law require that we condition our supply of fuel and technology on others accepting US approval rights over the use of US-origin materials", he told the congressional subcommittee. "Yet our imposition of conditions on supply necessarily reduces the confidence of others that they will have access to fuel and technology.'

Various ideas on how to get round this difficulty in the light of the INFCE results are now being discussed. Drawing on INFCE's conclusion that the economics of reprocessing appear to be marginal, for example, Mr Smith has proposed that the US agree to reprocessing by other countries wherever the demand for plutonium is dictated by the needs of fast breeder and advanced reactor research - but not where it is needed merely to manage spent fuel.

Other suggestions being pursued by the State Department are that longer-term licensing could replace current individual requests to transfer and reprocess spent fuel from states with good non-proliferation credentials, and various types of back-up fuel supply arrangements, perhaps with one country agreeing to meet commitments if another country defaults.

Whether changes in emphasis within the existing legislation will be sufficient to meet the objections of critics remains to be seen. Certainly the outcome of INFCE has done little to shift the reluctance of the member countries of Euratom to renegotiate its uranium supply agreements with the US, as required by the NNPA.

Similarly, even if Britain adopts a Westinghouse design for its next thermal reactors, the provisions of the act could lead it to reject Westinghouse as a supplier

\section{Non-proliferation act}

The Nuclear Non-Proliferation Act which was signed by President Carter in 1978 is an attempt to limit the proliferation of nuclear weapons by tightening restrictions on the supply of nuclear fuels and facilities by the US to foreign countries.

The act was prompted by India's explosion of a nuclear device in 1974 using nuclear fuel and technology initially provided by Canada for energy purposes. It forbids the supply of nuclear fuels, reactors or reactor components to countries not possessing nuclear weapons which explode nuclear test devices, or which otherwise violate safeguards developed by the international atomic energy authority.

A decision to refuse an export licence for such fuel or reactor components can, however, be overturned by the President if it is considered that such action would be "seriously prejudicial to the achievement of United States non-proliferation objectives or otherwise jeopardize the common defense and security." The President's action can in turn be vetoed by Congress.

In addition, the act provides that no nuclear fuel or technology exported from the US can be retransferred to the jurisdiction of any other nation or group of nations without the prior approval of the US. Nor can spent nuclear fuel either originating in the US or produced with technology from the US be reprocessed without US approval. 
of major components, such as the reactor vessel and circulation pumps. Under the current terms of the act, the US would have control over any fuel once it had been irradiated using such components.

But opposition to a change in policy is firmly entrenched, particularly from those convinced of President Carter's correctness in opposing any measures that would increase the spread of plutonium. "The choice between us is not between 'leverage' and 'consensus', rather it is between sticking to our principles and abandoning them" says Dr Tom Cochran, senior staff scientist with the Natural Resources Defense Council.

Given the apparent depth of the President's previous commitment to this position, no substantial change of policy is expected, at least until after the forthcoming elections. But there are several hurdles to be met before then, in particular the Nuclear Non-Proliferation Treaty review conference which takes place in Geneva in August.

Faced with inevitable criticism for failing to secure progress towards an arms limitation agreement with the Soviet Union, the US is hoping to reply by pointing to its efforts in support of INFCE's warnings about the proliferation dangers inherent in reprocessing and fast breeders - and to the steps it is taking to enhance its image as a reliable nuclear supplier to states which sign the NPT.

But it is a long shot. US officials admit that they are faced with a no-win situation at the review conference, and that their prime tactic is likely to be 'damage limitation' rather than anything more ambitious.

David Dickson

\section{Electric vehicles}

\section{Top speed at Lords}

What will the House of Lords make of the electric car, the topic on which the Select Committee on Science and Technology appointed in January (Nature 20 March, page 199) chose to cut its teeth? Nobody is yet sure. But anxious, no doubt,

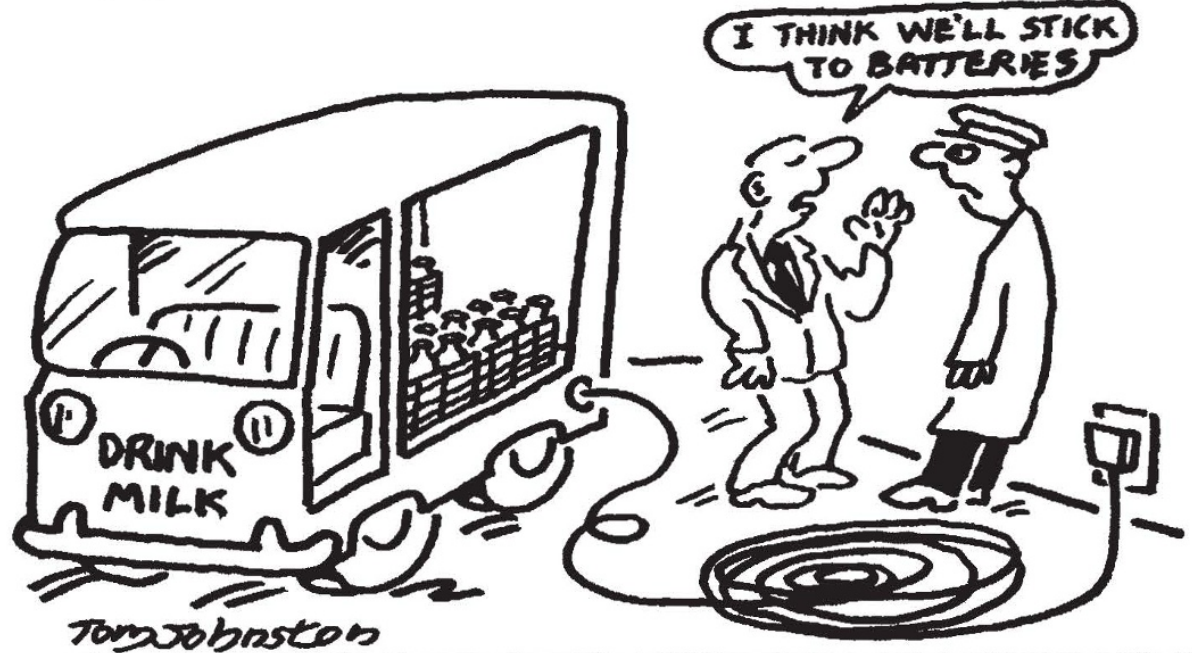

to fulfil its promise that the inquiry should be short and sharp, the committee has now finished taking evidence and plans to publish its report in July. Electric vehicles are in the same class as saints used to be: everybody approves provided they work. The perennial problem is whether the energy density of the batteries that drive electric vehicles can be increased substantially above that of the lead-acid battery, rated at 150 kilo-Joules $\mathrm{kg}^{-1}$ at full charge.

The committee has heard from the chief British battery makers, Chloride and Lucas, that the brightest prospects for increasing energy densities by a factor of between three and four lie with the sodiumsulphur battery. Unfortunately though, vehicle operators would have to put up with the inconvenience of batteries working at $350^{\circ} \mathrm{C}$. So nickel-zinc batteries now seem to be the gleam in manufacturers' eyes.

Several witnesses have told the House of Lords that Britain spends little on electric vehicle research compared with the United States and Japan. About $£ 20$ million has been spend since the late 1960 s, about $75 \%$ of which has been put up by private industry. The US, by contrast, has a sevenyear $\$ 200$ million programme which began in 1976. Yet Britain has the largest fleet of electric vehicles $-45,000$ of them, mostly used for delivering milk.

The prospects for further and rapid growth of the electric vehicle fleet in the UK are not however bright. Chloride/ Talbot and Lucas/Vauxhall have built small fleets of delivery vans (top speed 50 miles per hour and range 50 to 70 miles), which are now operating in several cities. They hope to achieve commercial production in the mid-1980s.

But the manufacturers are cool about the prospects for the all-electric private car. The most promising way of increasing speed and range is by mean of the hybrid vehicle running on part petrol, part battery. US manufacturers seem to be much keener on this development than their UK counterparts who are deterred by the problems of incorporating two different systems within one vehicle. A

\section{THINK WELL STICK}

